medRxiv preprint doi: https://doi.org/10.1101/2020.06.04.20122119; this version posted June 5, 2020. The copyright holder for this preprint (which was not certified by peer review) is the author/funder, who has granted medRxiv a license to display the preprint in perpetuity. it is made available under a CC-BY 4.0 internationallicense.

The impact of occupational risk from COVID on GP supply in England: A crosssectional study.

Miqdad Asaria, Assistant Professorial Research Fellow, London School of Economics and Political Science, Houghton Street, London WC2A 2AE, m.asaria@lse.ac.uk

Rebecca Fisher, Senior Policy Fellow, The Health Foundation, 8 Salisbury Square, London EC4Y 8AP

\title{
Abstract
}

Objectives To identify the risk of general practitioner mortality from COVID and the impact of measures to mitigate this risk on the level and socioeconomic distribution of primary care provision in the English NHS

Design Cross sectional study

Setting All GP practices providing primary care under the NHS in England

Participants 45,858 GPs and 6,771 GP practices in the English NHS

Main outcome measures Numbers of high-risk GPs, high-risk single-handed GP practices, patients associated with these high-risk single-handed practices and the regional and socioeconomic distribution of each. Mortality rates from COVID by age, sex and ethnicity were used to attribute risk to GPs and the Index of Multiple Deprivation was used to determine socioeconomic distributions of the outcomes.

Results Of 45,858 GPs in our sample 3,632 (7.9\%) were classified as high risk or very high risk. Of 6,771 GP practices in our sample 639 (9.4\%) were identified as singlehanded practices and of these 209 (32.7\%) were run by a GP at high or very high risk. These 209 single-handed practices care for 710,043 patients. GPs at the highest levels of risk from COVID, and single-handed practices run by high-risk GPs were concentrated in the most deprived neighbourhoods in the country. London had the highest proportion of both GPs and single-handed GP practices at very high risk of COVID mortality with 1,160 patients per 100,000 population registered to these practices.

Conclusions A significant proportion of GPs working in England, particularly those serving patients in the most deprived neighbourhoods, are at high risk of dying from COVID. Many of these GPs run single-handed practices. These GPs are particularly concentrated in London. There is an opportunity to provide additional support to mitigate COVID risk for GPs, GP practices and their patients. Failure to do so will likely exacerbate existing health inequalities. 
medRxiv preprint doi: https://doi.org/10.1101/2020.06.04.20122119; this version posted June 5, 2020. The copyright holder for this preprint (which was not certified by peer review) is the author/funder, who has granted medRxiv a license to display the preprint in perpetuity. It is made available under a CC-BY 4.0 International license .

\section{What is already known:}

- Known risk factors for morbidity and mortality from COVID-19 include age, sex, ethnicity and certain underlying health conditions.

- NHS England have suggested that NHS staff who may be at higher risk from COVID are risk assessed and have their activities adjusted accordingly, including ceasing face to face patient contact.

\section{What this study adds:}

- This study applies risk scoring to calculate the number of GPs practicing in England who are likely to be at high or very high risk of death from COVID. We examine the potential effect of removing GPs at high or very high risk from COVID from face to face patient contacts, estimating the number of GPs and patients likely to be affected, and relating this to deprivation and geography.

- We estimate that of 45,858 GPs in our sample, 2,253 (4.9\%) were classified as high risk, and 1,379 (3\%) as very high risk from COVID. These are likely to be conservative estimates.

- GPs at high risk of COVID are more likely to work in areas of high socioeconomic deprivation.

- Almost one in three single-handed GP practices (32.7\%, or 209 out of 639 ) is run by a GP we estimate to be at high or very high risk from COVID. If these GPs did not see patients face to face, 710,043 patients would be left without face to face GP appointments. Single-handed GP practices in areas of high socioeconomic deprivation are more likely to be run by GPs at higher risk of COVID.

\section{Introduction}

As the NHS shifts to the 'second phase' of responding to the COVID-19 ('COVID') pandemic, learning how to live and work alongside COVID is necessary. In general practice this will be challenging. Strategies already in use are likely to be maintained, including using 'hot hubs', 'zoning' and using telephone and video consulting to reduce face to face contact where possible. But these can only go so far. The number of patients requiring face to face consultations is likely to creep up over time (as examinations and tests can no longer be deferred), and with it the exposure of general practitioners (GPs) to COVID.

The risk of catching COVID - and of dying from it - is not equally distributed amongst GPs. Relatively early in the pandemic, Public Health England issued guidance identifying three risk factors used to guide managers in conversations with staff about increased vulnerability to COVID: age $>70$ years, selected underlying health 
medRxiv preprint doi: https://doi.org/10.1101/2020.06.04.20122119; this version posted June 5, 2020. The copyright holder for this preprint (which was not certified by peer review) is the author/funder, who has granted medRxiv a license to display the preprint in perpetuity. it is made available under a CC-BY 4.0 International license.

conditions, and pregnancy.(1) Although ethnicity was not originally included as a risk factor this has since been recognised as an important omission. Morbidity and mortality from COVID is higher in Black, Asian and Minority Ethnic (BAME) people than in Caucasian people, and the vast majority of COVID deaths in healthcare workers have been BAME staff, despite BAME workers accounting for $21 \%$ of the NHS workforce.(2-4)

The NHS Risk Reduction Framework attempts to capture this differential risk, with suggestion made - since reiterated in a letter from NHS England - that NHS employees deemed to be at higher risk from COVID be re-deployed to roles without face to face contact. $(5,6)$ Unlike in secondary care, where individuals often work as part of large teams, GPs tend to work in smaller teams, and sometimes as the sole medical practitioner in a surgery (so called 'single handed' practice). The impact of removing GPs from face to face patient duties may be harder to compensate for, and in some cases may leave an entire patient population without a GP with whom they can face to face consult in a manner that is safe for GP and patient.

This analysis seeks to understand the potential implications of applying COVIDrelated occupational risk assessment to GPs. We calculate how many GPs currently practicing in England are likely to fall within high risk groups, whether those GPs are concentrated in particular geographical areas, and the correlation of this with socioeconomic deprivation - a known predictor of GP workload. We also calculate the number of single-handed practices being run by GPs likely to be deemed at high risk from COVID, and the number of patients covered by these GPs.

\section{Methods}

\section{Workforce data}

We used Primary care workforce data from the most recent release of the General Practice Workforce series published by NHS Digital for the $31^{\text {st }}$ March 2020.(7) This dataset includes details on all NHS GPs as well as all NHS GP Practices operating in England. Data on individuals in this data series was used to categorise GPs by age, sex, country of qualification, primary job role and clinical commissioning group. The data series on GP Practices was used to identify single-handed GP practices as those run by a single GP (excluding locums, registrars and retainers who may work at the practice). GPs and practices lacking data on GP age and sex were excluded as meaningful judgements on risk of COVID mortality could not be made without these key characteristics. This resulted in 1,615 (3.4\%) of GPs and 4 (0.06\%) of singlehanded GP practices being excluded from our dataset.

Age-specific COVID mortality rates

Age and sex specific mortality data covering the period between the $1^{\text {st }}$ March 2020 and $30^{\text {th }}$ April 2020 from the Office of National Statistics (ONS) were used to capture deaths from COVID.(8) This mortality data was combined with age and sex specific population data from ONS mid-year population estimates for 2019 to calculate agesex specific COVID mortality rates.(9) 
medRxiv preprint doi: https://doi.org/10.1101/2020.06.04.20122119; this version posted June 5, 2020. The copyright holder for this preprint (which was not certified by peer review) is the author/funder, who has granted medRxiv a license to display the preprint in perpetuity. t is made available under a CC-BY 4.0 international license.

\section{Socioeconomic distribution of Clinical Commissioning Groups}

The Index of Multiple Deprivation (IMD) 2019 measures relative deprivation in small areas in England called lower-layer super output areas (LSOAs).(10) We attributed IMD scores from LSOAs to CCGs by calculating population weighted averages, and used these attributed scores to rank CCGs into population weighted deprivation quintile groups with each quintile group of CCGs covering approximately a fifth of the total population.(11-13) A table detailing the CCG deprivation quintiles we calculated for use in this analysis is provided in the supplementary appendix (Table A2).

\section{COVID risk reduction framework}

We used the Risk Reduction Framework for NHS Staff at risk of COVID infection to guide our understanding of key characteristics that contribute to the level of risk from COVID faced by GPs.(5) The framework highlights age, sex, ethnicity, underlying health conditions and pregnancy as the five most important factors that influence risk from COVID among NHS staff. We also considered the Safety Assessment And Decision (SAAD) score designed to assess risks for BAME communities during a COVID pandemic infection in general practice which highlights similar factors as contributing to mortality risk using a more detailed treatment of ethnicity and underlying health conditions.(14) We used data on age, sex and ethnicity to characterise risk amongst GPs using the age-groups and ethnicity categories suggested in the framework. Data on underlying health conditions and pregnancy were not available in the workforce data so we were unable to include these in our analysis. Additionally, ethnicity data was not provided in the data so we used country of qualification as a proxy for ethnicity assuming that GPs listed as qualifying either in the United Kingdom (UK) or the European Economic Area (EEA) as being White whilst GPs listed as qualifying anywhere else were characterised as BAME. Our ethnicity variable therefore mis-categorises those BAME GPs that qualified in the UK or EEA as White and hence will under-estimate COVID risk associated with these GPs. We have requested bespoke datasets from NHS Digital and the General Medical Council that explicitly include ethnicity and will update the analysis in this manuscript with more accurate ethnicity data if we are able to obtain these data.

\section{COVID risk categorisation of GPS}

We used the age-sex specific COVID mortality rates we calculated to translate the risk reduction framework into a risk scoring system. Risk scores were calculated by dividing all mortality rates by those for women aged 55-60 (the lowest risk group for whom COVID mortality risk is non-negligible). These scores were adjusted for ethnicity using a recent ONS study that found that age and sex adjusted COVID mortality rates for non-White ethnic groups are between 2 times and 4 times those of Whites depending on which non-White ethnic group is being compared.(15) Two alternative sets of risk scores were calculated for BAME GPs by using the upper and lower range of these ethnicity specific adjustments respectively to adjust the overall age-sex specific risk scores. We used the resulting risk scores to categorise both GPs and single-handed GP practices into 4 risk categories (Low, Medium, High and Very High) to reflect risk of mortality from COVID. 
medRxiv preprint doi: https://doi.org/10.1101/2020.06.04.20122119; this version posted June 5, 2020. The copyright holder for this preprint (which was not certified by peer review) is the author/funder, who has granted medRxiv a license to display the preprint in perpetuity. t is made available under a CC-BY 4.0 international license.

\section{Outcome measures}

Our main outcome measures were (1) numbers of GPs, (2) number of single-handed GP practices and (3) numbers of patients registered to single-handed GP practices. Each outcome measure was disaggregated by COVID risk category to identify the numbers of GPs, single-handed practices and patients registered to single-handed practices at high and very high risk levels. The regional and socioeconomic distribution of high and very high COVID risk in primary care was examined for each outcome measure.(16)

\section{Software}

All analysis was conducted using R version 4.0.0 statistical software.(17)

\section{Results}

Age-sex specific COVID mortality rates show that risk increases rapidly with age, with risk of dying from COVID in those over 70 years of age being approximately a hundred times higher than risk for those under 55 years of age (see Table 1). Additionally we see that at any given age, risk for men is approximately double that for women.

The results of converting these mortality rates into risk scores and adding ethnicity specific adjustments to get Risk Scores A and B, in which BAME GPs have double or quadruple the risk of white GPs of the same age and sex respectively are shown in Table 2. Using either risk scoring system we find that GPs under 55 years of age regardless of sex or ethnicity are at the lowest risk whilst those over 70 years old are at the highest risk. We categorise GPs into four categories based on these risk scores: Low (0-1 points), Medium (1-4), High (4-9) and Very High (>9). Risk categories were defined to reflect discontinuities in the risk scores. Table 2 shows that the highest risk GPs in each of the risk categories is at approximately half the risk as the lowest risk GPs in the next risk category. The categorisation we have used works for both Risk Scores A and B and is robust to the choice of ethnicity adjustment.

Summary statistics describing the 45,858 GPs and 639 single hander GP practices used in our analysis are given in Table 3 . The vast majority of GPs (86.2\%) and just over half of single-handed GP practices are classed as low risk. 4.9\% of GPs and $14.9 \%$ of single-handed GP practices are classed as high risk and $3.0 \%$ of GPs and $17.8 \%$ of single-handed GP practices are classed as very high risk. Increased risk is particularly concentrated in single-handed practices almost $1 / 3$ of which are run by a GP at high or very high risk from COVID.

Breaking down the GP workforce into age, sex and ethnicity groups (see Figure 1) shows that almost all GPs over the age of 70 are also of BAME ethnicity. We also see that locums are substantially over-represented amongst very high risk GPs, making up $17 \%$ of very high risk GPs (see Figure 1) whilst constituting less than $10 \%$ of the overall GP workforce (see Table 3). Full breakdowns of GPs by age, sex, ethnicity, risk group and job role are given in the supplementary appendix Table A2. 
medRxiv preprint doi: https://doi.org/10.1101/2020.06.04.20122119; this version posted June 5, 2020. The copyright holder for this preprint (which was not certified by peer review) is the author/funder, who has granted medRxiv a license to display the preprint in perpetuity. t is made available under a CC-BY 4.0 international license.

Examining the distribution of GPs according to the deprivation quintile of the CCG in which they practice (see Figure 2 ) we find that there is a steep socioeconomic gradient in the distribution of very high risk GPs. Very high risk GPs are more than 3 times as likely to be working in the most deprived CCGs in the country as they are to be working in the most affluent CCGs.

The socioeconomic distribution of single-handed GP practices displays an even steeper deprivation gradient (see Figure 3). Single-handed practices run by GPs classed as being at very high risk are more than 4 times as likely to be located in the most deprived CCGs in the country as compared to in the most affluent CCGs. We can also examine this through the numbers of patients registered to these singlehanded practices (see Figure 4). There are 126,412 patients registered to singlehanded GP practices classed as being at very high risk located in the most deprived CCGs in the country as compared to 33,745 patients registered to single-handed GP practices classed as very high risk located in the most affluent CCGs.

Examining the regional distribution of our three outcome measures (see Figure 5) we see that London has the highest proportions of very high risk GPs (5.2 very high risk GPs per 100,000 population), very high risk single-handed GP practices ( 0.37 very high risk single-handed GP practices per 100,000 population) and patients registered to very high risk single-handed GP practices $(1,160$ patients registered to very high risk single-handed GP practices per 100,000 population). Full breakdowns of our main outcomes by region are detailed in the supplementary appendix Table A6.

\section{Discussion}

\section{Statement of principle findings}

Although the majority of GPs practicing in England are at low risk of death from COVID, a significant proportion of GPs, 7.9\% (3,632 GPs) are at high or very high risk. These GPs are more likely to work in areas of high socioeconomic deprivation. Almost one in three single handed GP practices (32.7\%) is run by a GP at high or very high risk from COVID. These single-handed GP practices are even more heavily concentrated in areas of high deprivation, particularly in London.

\section{Strengths and weaknesses:}

Our study is the first that we are aware of that explores the potential impact of COVID across the GP workforce in the NHS. We use a comprehensive national dataset to quantify the degree of fragility of primary care in the face of the COVID pandemic and highlight the particularly vulnerable position of single-handed GP practices in the delivery of primary care in these times. We also explore the implications of these risks on the regional and socioeconomic distributions of primary care provision and find that risks are patterned by both geography and deprivation. If left un-mitigated, existing health inequalities amongst the patient population are likely to be exacerbated along these dimensions. 
medRxiv preprint doi: https://doi.org/10.1101/2020.06.04.20122119; this version posted June 5, 2020. The copyright holder for this preprint (which was not certified by peer review) is the author/funder, who has granted medRxiv a license to display the preprint in perpetuity. it is made available under a CC-BY 4.0 internationallicense.

Our study builds on emerging frameworks that identify COVID risk amongst healthcare staff in the NHS. $(5,14)$ These frameworks were written to identify risk at the individual level, requiring detailed information about underlying health conditions and biomarkers of those being assessed. Our attempt to operationalise these frameworks at a health system level is challenging and has a number of limitations. First, detailed data on underlying health conditions, pregnancy, and biomarkers such as BMI and Vitamin D levels that are found in these frameworks are not recorded in the comprehensive national data sets that cover the NHS workforce underpinning our analysis. We were therefore unable to use these factors in our implementations of the COVID risk scores. Consideration of these additional factors if they were available would re-classify some GPs as being at higher risk than the risk level attributed to them in our analysis. Hence, the numbers of GPs we report to be at high COVID risk should be seen as conservative. Second, we were unable to obtain explicit data on ethnicity from the datasets used in our analysis. We instead had to use country of qualification as a proxy for ethnicity. This under-estimates the number of BAME people in our dataset assuming all GPs trained in the UK and EEA are White. The effect of this is likely to be a further under-estimation of the number of GPs at high risk from COVID. To get a sense of the magnitude of this bias we note that $23.9 \%$ of GPs in our dataset are classified as being of BAME ethnicity as compared to $44 \%$ of all doctors in the NHS.(18) We have requested bespoke data from NHS Digital and the GMC to explicitly capture ethnicity in our analysis and will update our results should this data become available to us.

Finally, we examined the socioeconomic distribution of high COVID risk GPs and single-handed GP practices using CCG level deprivation scores. CCGs cover large and heterogeneous populations and much of the granularity of the impacts of deprivation are masked when used at this coarse level of geography. Unfortunately, the datasets underpinning our analysis were unable to provide finer grained information on the geographical distribution of GPs and so we were limited by the data to perform our socioeconomic analysis at CCG level. We therefore expect that the socioeconomic gradients highlighted by our analysis will be much steeper in reality and could be better estimated if more granular geographic data on the distribution of GPs was available.

\section{Implications for policymakers}

COVID creates numerous challenges for policy makers and commissioners, and amidst the inevitable focus on 're-opening' secondary care, the implications of coexisting with COVID in general practice must not be overlooked. Maintaining general practice as a 'front door' to the NHS that is safe for both GPs and patients is vital but not easy. Options to quarantine and pre-test patients intended to help protect secondary care cannot be deployed in primary care. Precautions will be taken, but patient-facing members of the primary care team will be exposed to risk from COVID. Measures intended to protect higher risk GPs from COVID are likely to be necessary for some time, and may vary over time depending on COVID incidence and prevalence. 
medRxiv preprint doi: https://doi.org/10.1101/2020.06.04.20122119; this version posted June 5, 2020. The copyright holder for this preprint (which was not certified by peer review) is the author/funder, who has granted medRxiv a license to display the preprint in perpetuity. it is made available under a CC-BY 4.0 internationallicense.

Withdrawing 'high risk' GPs from face to face consulting does not necessarily mean removing them from the clinical workforce. Doctors who are unable to see patients face to face may continue to consult via other means, including telephone and video consulting. Some 'high risk' GPs may decide to continue to see patients 'as usual'. But surgeries need to plan for how to cover gaps in the provision of face to face appointments, acknowledging that the duration of GPs absence from face to face work is unknown. The scale of this challenge will vary depending on factors including the number of other GPs working at the same practice, and the COVID risk status of those GPs. Where a 'single handed' GP falls into a high risk group, practices may have no face to face provision at all. If GPs at higher risk do continue to practice face to face there is a greater than average risk that their ability to do so may be restricted by illness or death from COVID.

The impact of a reduction in GPs able to consult face to face is not evenly distributed geographically or by socioeconomic deprivation. This is likely to exacerbate inequalities in GP workload and funding which existed prior to COVID, and which result in GPs in areas of higher deprivation having a proportionately higher workload, with relative under-funding.(19-22) Our analysis shows a steep deprivation gradient. If GPs at higher risk of COVID stop seeing patients face to face, the reduction in provision will be greatest in the most deprived areas. These are the areas where overall health need is greatest, and where morbidity and mortality from COVID is likely to be greater too. $(23,24)$ There are also concerns that alternatives to face to face consulting such as video consultations may be harder to access for deprived populations, and those with additional barriers to care such as English as a second language.

As GPs are likely to feel the weight of responsibility for their patients, local systems must work together - at primary care network and CCG level - to ensure that GPs are able to make the right personal choices for themselves around COVID risk, safe in the knowledge that patient care will not suffer. Increasing collaboration between surgeries in primary care networks may be one avenue for this, and exploring a locum market significantly changed by COVID is another.(25)

\section{Unanswered questions and future research}

Analysis of occupational health risk from COVID should be expanded to include assessment of wider general practice teams, including allied health professionals and administrative support. Although the implications for face to face consulting may be different, risk assessment for the entire patient-facing practice staff must not be overlooked, particularly in light of evidence suggesting that COVID risk may be higher in less well paid roles.(26)

This study alerts us to a relatively large number of GPs at high risk of mortality from COVID, and to geographical and socioeconomic variation in the distribution of affected GPs. We do not know how many of these GPs will in practice choose to step away from direct patient contact, and how this may vary over time. Further work will be required to track what actually happens, and the effect on patient care of a 
medRxiv preprint doi: https://doi.org/10.1101/2020.06.04.20122119; this version posted June 5, 2020. The copyright holder for this preprint (which was not certified by peer review) is the author/funder, who has granted medRxiv a license to display the preprint in perpetuity. It is made available under a CC-BY 4.0 International license.

possible reduction in the number of GPs able to consult face to face. There is a timely opportunity to provide additional support to mitigate COVID-19 risk for high risk GPs, GP practices and their patients. Failure to do so will likely further exacerbate existing health inequalities.

\section{Acknowledgements:}

The authors would like to acknowledge helpful comments from Health Foundation colleagues.

\section{Data sharing statement:}

All data used in this study is publicly available administrative data. The data sources have been highlighted in the methods section of the manuscript. Code for all the analyses as well as the anonymised database will be made available on reasonable request. 
medRxiv preprint doi: https://doi.org/10.1101/2020.06.04.20122119; this version posted June 5, 2020. The copyright holder for this preprint (which was not certified by peer review) is the author/funder, who has granted medRxiv a license to display the preprint in perpetuity. t is made available under a CC-BY 4.0 international license.

\section{References:}

1. Issar P. HR updates and guidance - Annex 2: Supporting our vulnerable staff [Internet]. NHS England and NHS Improvement; 2020 Mar. Available from: https://www.england.nhs.uk/coronavirus/wpcontent/uploads/sites/52/2020/03/annex-2-supporting-our-vulnerable-staff.pdf

2. Marsh S, Mclntyre N. Six in 10 UK health workers killed by Covid-19 are BAME. The Guardian [Internet]. 2020 May 25 [cited 2020 Jun 1]; Available from: https://www.theguardian.com/world/2020/may/25/six-in-10-uk-healthworkers-killed-by-covid-19-are-bame

3. Cook T, Kursumovic E, April 2020 SL. Exclusive: deaths of NHS staff from covid-19 analysed [Internet]. Health Service Journal. 2020 [cited 2020 Jun 1]. Available from: https://www.hsj.co.uk/exclusive-deaths-of-nhs-staff-from-covid-19analysed/7027471.article

4. Disparities in the risk and outcomes of COVID-19 [Internet]. Public Health England; 2020 Jun. Available from:

https://assets.publishing.service.gov.uk/government/uploads/system/uploads/a ttachment_data/file/889195/disparities_review.pdf

5. Khunti K, de Bono A, Browne I, Greenhalgh T, Hanif W, Majeed A, et al. Risk Reduction Framework for NHS Staff at risk of COVID-19 infection [Internet]. Faculty of Medicine; 2020 May p. 44. Available from: https://www.fom.ac.uk/wp-content/uploads/Risk-Reduction-Framework-forNHS-staff-at-risk-of-COVID-19-infection-12-05-20.pdf

6. Stevens S, Pritchard A. IMPORTANT - FOR ACTION - SECOND PHASE OF NHS RESPONSE TO COVID19 [Internet]. 2020. Available from: https://www.england.nhs.uk/coronavirus/wpcontent/uploads/sites/52/2020/04/second-phase-of-nhs-response-to-covid-19letter-to-chief-execs-29-april-2020.pdf

7. General Practice Workforce - 31 March 2020 [Internet]. NHS Digital. 2020 [cited 2020 Jun 1]. Available from: https://digital.nhs.uk/data-andinformation/publications/statistical/general-and-personal-medicalservices/final-31-march-2020

8. Campbell A, Caul S. Deaths involving COVID-19, England and Wales [Internet]. Office for National Statistics. 2020 [cited 2020 Jun 1]. Available from: https://www.ons.gov.uk/peoplepopulationandcommunity/birthsdeathsandmarri ages/deaths/datasets/deathsinvolvingcovid19englandandwales

9. Park N. Estimates of the population for the UK, England and Wales, Scotland and Northern Ireland [Internet]. Office for National Statistics. [cited 2020 Jun 1].

Available from:

https://www.ons.gov.uk/peoplepopulationandcommunity/populationandmigrati on/populationestimates/datasets/populationestimatesforukenglandandwalessc otlandandnorthernireland 

medRxiv preprint doi: https://doi.org/10.1101/2020.06.04.20122119; this version posted June 5 , 2020. The copyright holder for this preprint
(which was not certified by peer review) is the author/funder, who has granted medRxiv a license to display the preprint in perpetuity. t is made available under a CC-BY 4.0 International license.

10. English indices of deprivation 2019 [Internet]. Ministry of Housing, Communities \& Local Government. 2019 [cited 2020 Jun 1]. Available from:

https://www.gov.uk/government/statistics/english-indices-of-deprivation-2019

11. Park N. Lower layer Super Output Area population estimates mid-2018 [Internet]. Office for National Statistics. 2019 [cited 2020 Jun 1]. Available from: https://www.ons.gov.uk/peoplepopulationandcommunity/populationandmigrati on/populationestimates/datasets/lowersuperoutputareamidyearpopulationesti mates

12. Lower Layer Super Output Area (2011) to Clinical Commissioning Group to Local Authority District (April 2019) Lookup in England [Internet]. Office for National Statistics. 2019 [cited 2020 Jun 1]. Available from: https://geoportal.statistics.gov.uk/datasets/lower-layer-super-output-area2011-to-clinical-commissioning-group-to-local-authority-district-april-2019lookup-in-england

13. Changes to Organisation Reference Data: sustainability and transformation partnerships reconfiguration [Internet]. NHS Digital. 2020 [cited 2020 Jun 1]. Available from: https://digital.nhs.uk/services/organisation-dataservice/changes-to-ord-stp-reconfiguration

14. Jiva M, Chauhan Z, Choudry B, Butt F, Omofuma OJ, Atcha Z, et al. Safety Assessment And Decision (SAAD) Score [Internet]. Available from: https://abmacademy.com/wp-content/uploads/2020/05/SAAD-Score-2.pdf

15. White C, Nafilyan V. Coronavirus (COVID-19) related deaths by ethnic group, England and Wales [Internet]. Office for National Statistics. 2020 [cited 2020 Jun 1]. Available from:

https://www.ons.gov.uk/peoplepopulationandcommunity/birthsdeathsandmarri ages/deaths/articles/coronavirusrelateddeathsbyethnicgroupenglandandwales/ 2march2020to10april2020

16. NHS England Regions (April 2020) Boundaries EN BUC [Internet]. Office for National Statistics. 2020 [cited 2020 Jun 1]. Available from: https://geoportal.statistics.gov.uk/datasets/nhs-england-regions-april-2020boundaries-en-buc

17. R Core Team. R: A Language and Environment for Statistical Computing [Internet]. Vienna, Austria: R Foundation for Statistical Computing; 2020. Available from: https://www.R-project.org/

18. NHS workforce [Internet]. Ethnicity facts and figures. 2020 [cited 2020 Jun 1]. Available from: https://www.ethnicity-facts-figures.service.gov.uk/workforceand-business/workforce-diversity/nhs-workforce/latest\#by-ethnicity-and-typeof-role

19. Gershlick B, Fisher R. A worrying cycle of pressure for GPs in deprived areas [Internet]. The Health Foundation. 2019 [cited 2020 Jun 1]. Available from: 
medRxiv preprint doi: https://doi.org/10.1101/2020.06.04.20122119; this version posted June 5, 2020. The copyright holder for this preprint (which was not certified by peer review) is the author/funder, who has granted medRxiv a license to display the preprint in perpetuity. It is made available under a CC-BY 4.0 International license .

https://www.health.org.uk/news-and-comment/blogs/a-worrying-cycle-ofpressure-for-gps-in-deprived-areas

20. Asaria M, Cookson R, Fleetcroft R, Ali S. Unequal socioeconomic distribution of the primary care workforce: whole-population small area longitudinal study. BMJ Open. 2016;6(1):e008783.

21. Boomla K, Hull S, Robson J. GP funding formula masks major inequalities for practices in deprived areas. Bmj. 2014;349.

22. Levene LS, Baker R, Bankart J, Walker N, Wilson A. Socioeconomic deprivation scores as predictors of variations in NHS practice payments: a longitudinal study of English general practices 2013-2017. Br J Gen Pract. 2019;69(685):e546-e554.

23. Stafford M, Steventon A, Thorlby R, Fisher R, Turton C, Deeny S. Understanding the health care needs of people with multiple health conditions [Internet]. London: The Health Foundation; 2018 Nov. Available from: https://www.health.org.uk/publications/understanding-the-health-care-needsof-people-with-multiple-health-conditions

24. Caul S. Deaths involving COVID-19 by local area and socioeconomic deprivation [Internet]. Office for National Statistics. 2020 [cited 2020 Jun 1]. Available from: https://www.ons.gov.uk/peoplepopulationandcommunity/birthsdeathsandmarri ages/deaths/bulletins/deathsinvolvingcovid19bylocalareasanddeprivation/death soccurringbetween1marchand17april

25. May 2020 21. Locums out of work: 'I never thought as a GP I would struggle to find work' [Internet]. Pulse Today. 2020 [cited 2020 Jun 1]. Available from: http://www.pulsetoday.co.uk/news/locums-out-of-work-i-never-thought-as-agp-i-would-struggle-to-find-work/20040850.article

26. Windsor-Shellard B, Kaur J. Coronavirus (COVID-19) related deaths by occupation, England and Wales: deaths registered up to and including 20 April 2020 [Internet]. Office for National Statistics. 2020. Available from: https://www.ons.gov.uk/peoplepopulationandcommunity/healthandsocialcare/ causesofdeath/bulletins/coronaviruscovid19relateddeathsbyoccupationengland andwales/deathsregistereduptoandincluding20april2020 
medRxiv preprint doi: https://doi.org/10.1101/2020.06.04.20122119; this version posted June 5, 2020. The copyright holder for this preprint (which was not certified by peer review) is the author/funder, who has granted medRxiv a license to display the preprint in perpetuity.

\section{Tables and figures:}

Table 1: COVID-19 deaths by age and sex per 100,000 population

\begin{tabular}{llrrc}
\hline & & & & \multicolumn{2}{c}{$\begin{array}{l}\text { COVID-19 deaths } \\
\text { COVID-19 }\end{array}$} & $\begin{array}{l}\text { per 100,000 } \\
\text { population }\end{array}$ \\
\hline Age Group & Sex & Population & Deaths & 3.8 \\
$<55$ & Male & $19,754,779$ & 757 & 2.3 \\
555 & Female & $19,395,980$ & 445 & 35.9 \\
$55-59$ & Male & $1,809,613$ & 650 & 16.2 \\
$60-69$ & Female & $1,861,038$ & 301 & 74.4 \\
$60-69$ & Male & $2,880,038$ & 2,143 & 34.5 \\
$70+$ & Female & $3,028,537$ & 1,044 & 413.3 \\
$70+$ & Male & $3,383,401$ & 13,984 & 270.3 \\
\hline
\end{tabular}

Note: population data from ONS 2019 mid-year populations, COVID-19 deaths from ONS deaths between $1^{\text {st }}$ March 2020 and $30^{\text {th }}$ April 2020

Table 2: COVID-19 risk categorisation based on mortality risk

\begin{tabular}{lllrrl}
\hline Age group & Sex & Ethnicity & $\begin{array}{c}\text { Risk Score A } \\
\text { (BAME = 2*White) }\end{array}$ & $\begin{array}{c}\text { Risk Score B } \\
\text { (BAME = 4*White) }\end{array}$ & COVID-19 Risk \\
\hline $70+$ & Male & BAME & 51.1 & 102.2 & very high \\
$70+$ & Female & BAME & 33.4 & 66.8 & very high \\
$70+$ & Male & White & 25.6 & 25.6 & very high \\
$60-69$ & Male & BAME & 9.2 & 18.4 & very high \\
$70+$ & Female & White & 16.7 & 16.7 & very high \\
$55-59$ & Male & BAME & 4.4 & 8.9 & high \\
$60-69$ & Female & BAME & 4.3 & 8.5 & high \\
$60-69$ & Male & White & 4.6 & 4.6 & high \\
$55-59$ & Female & BAME & 2 & 4 & medium \\
$55-59$ & Male & White & 2.2 & 2.2 & medium \\
$60-69$ & Female & White & 2.1 & 2.1 & medium \\
$55-59$ & Female & White & 1 & 1 & low \\
$<55$ & Male & BAME & 0.5 & 0.9 & low \\
$<55$ & Female & BAME & 0.3 & 0.6 & low \\
$<55$ & Male & White & 0.2 & 0.2 & low \\
$<55$ & Female & White & 0.1 & 0.1 & low \\
\hline
\end{tabular}

Notes: BAME = Black, Asian and Minority Ethnic, age-groups based on those used in the NHS risk reduction framework, GPs with missing data on age, sex or ethnicity classed with COVID-19 risk level Unknown 
medRxiv preprint doi: https://doi.org/10.1101/2020.06.04.20122119; this version posted June 5, 2020. The copyright holder for this preprint (which was not certified by peer review) is the author/funder, who has granted medRxiv a license to display the preprint in perpetuity. It is made available under a CC-BY 4.0 International license .

Table 3: Descriptive statistics for the 45,858 GPs and 639 single hander GP practices in England

\begin{tabular}{|c|c|c|c|c|}
\hline Characteristic & $\begin{array}{l}\text { Number } \\
\text { of GPs }\end{array}$ & $\begin{array}{l}\text { Proportion } \\
\text { of GPs (\%) }\end{array}$ & $\begin{array}{l}\text { Number of single } \\
\text { hander practices }\end{array}$ & $\begin{array}{l}\text { Proportion of single } \\
\text { hander practices (\%) }\end{array}$ \\
\hline \multicolumn{5}{|l|}{ Age group } \\
\hline$<55$ & 38,141 & $83.2 \%$ & 330 & $51.6 \%$ \\
\hline $55-59$ & 3,853 & $8.4 \%$ & 111 & $17.4 \%$ \\
\hline $60-69$ & 3,238 & $7.1 \%$ & 117 & $18.3 \%$ \\
\hline $70+$ & 626 & $1.4 \%$ & 81 & $12.7 \%$ \\
\hline \multicolumn{5}{|l|}{ Gender } \\
\hline Female & 25,603 & $55.8 \%$ & 194 & $30.4 \%$ \\
\hline Male & 20,255 & $44.2 \%$ & 445 & $69.6 \%$ \\
\hline \multicolumn{5}{|l|}{ Country of Qualification } \\
\hline UK \& EEA & 34,877 & $76.1 \%$ & 405 & $63.4 \%$ \\
\hline Other & 10,981 & $23.9 \%$ & 234 & $36.6 \%$ \\
\hline \multicolumn{5}{|l|}{ Job Role } \\
\hline GP Partners & 20,979 & $45.7 \%$ & 639 & $100 \%$ \\
\hline Salaried GPs & 13,519 & $29.5 \%$ & - & - \\
\hline GP Locums & 4,484 & $9.8 \%$ & - & - \\
\hline GP Registrars & 6,339 & $13.8 \%$ & - & - \\
\hline GP Retainers & 537 & $1.2 \%$ & - & - \\
\hline \multicolumn{5}{|l|}{ COVID-19 Risk Group } \\
\hline Low & 39,543 & $86.2 \%$ & 348 & $54.5 \%$ \\
\hline Medium & 2,683 & $5.9 \%$ & 82 & $12.8 \%$ \\
\hline High & 2,253 & $4.9 \%$ & 95 & $14.9 \%$ \\
\hline Very High & 1,379 & $3.0 \%$ & 114 & $17.8 \%$ \\
\hline \multicolumn{5}{|l|}{ Region } \\
\hline East of England & 4,600 & $10.0 \%$ & 67 & $10.5 \%$ \\
\hline London & 7,675 & $16.7 \%$ & 131 & $20.5 \%$ \\
\hline Midlands & 8,445 & $18.4 \%$ & 144 & $22.5 \%$ \\
\hline North East and Yorkshire & 6,815 & $14.9 \%$ & 97 & $15.2 \%$ \\
\hline North West & 5,782 & $12.6 \%$ & 136 & $21.3 \%$ \\
\hline South East of England & 6,851 & $14.9 \%$ & 58 & $9.1 \%$ \\
\hline South West of England & 4,927 & $10.7 \%$ & 6 & $0.9 \%$ \\
\hline Unknown & 763 & $1.7 \%$ & - & - \\
\hline \multicolumn{5}{|l|}{ IMD Quintile } \\
\hline Q1 most deprived & 9,331 & $20.3 \%$ & 239 & $37.4 \%$ \\
\hline Q2 & 8,713 & $19.0 \%$ & 146 & $22.8 \%$ \\
\hline Q3 & 9,332 & $20.3 \%$ & 111 & $17.4 \%$ \\
\hline Q4 & 8,707 & $19.0 \%$ & 84 & $13.1 \%$ \\
\hline Q5 least deprived & 9,012 & $19.7 \%$ & 59 & $9.2 \%$ \\
\hline Unknown & 763 & $1.7 \%$ & - & - \\
\hline
\end{tabular}

Notes: Data from the NHS Digital General Practice Workforce for 31 March 2020, COVID-19 risk scores: Low (0-1), Medium (1-4), High (4-9), Very High (>9), IMD = Index of Multiple Deprivation 2019 population weighted ranks at CCG level 
Figure 1: GP workforce breakdown by COVID-19 mortality risk

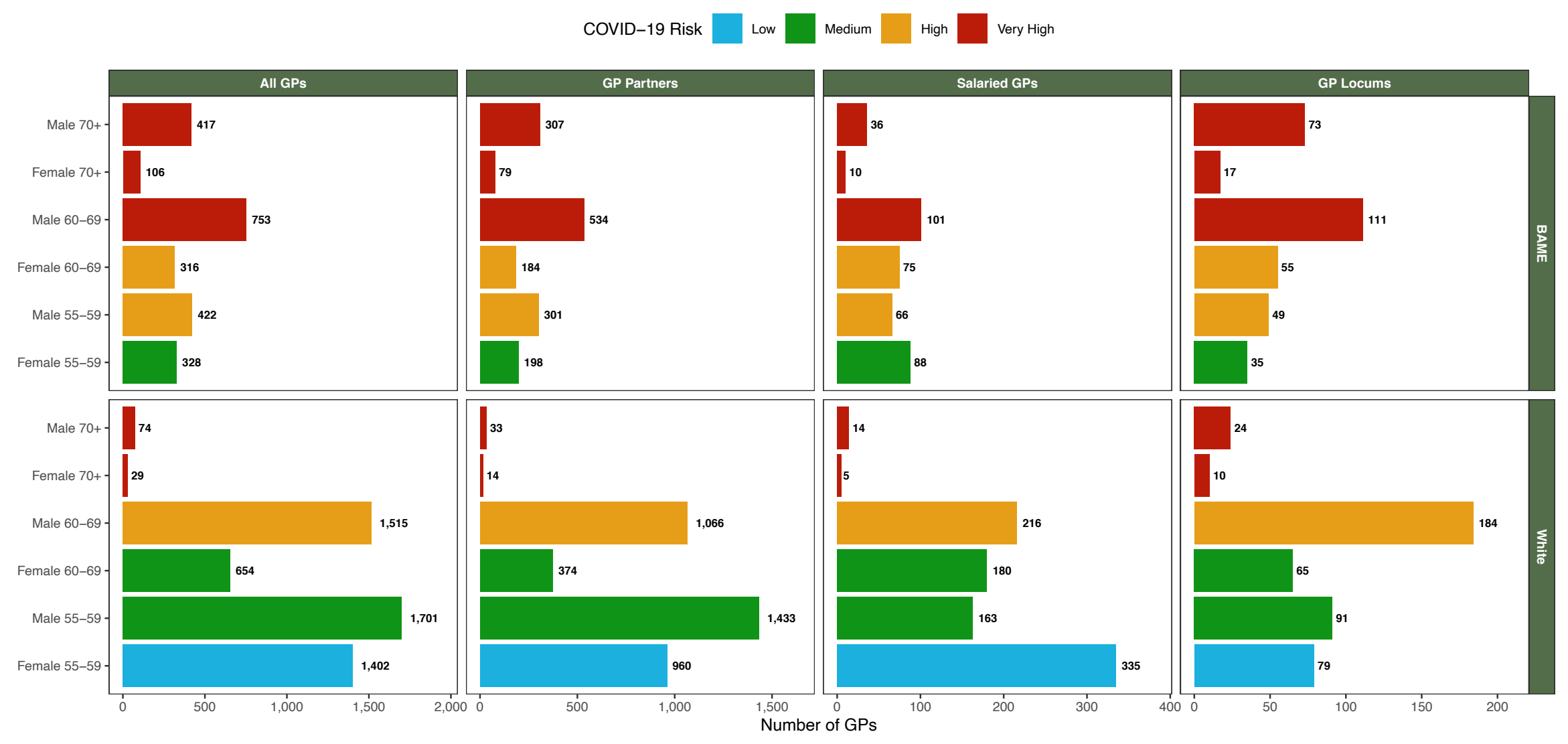

Notes: Data from the NHS Digital General Practice Workforce for 31 March 2020, COVID-19 risk scores: Low (0-1), Medium (1-4), High (4-9), Very High (>9), showing all GPs over 55 years of age 
Figure 2: Socioeconomic distribution of GPs with high and very high risk of COVID-19 mortality
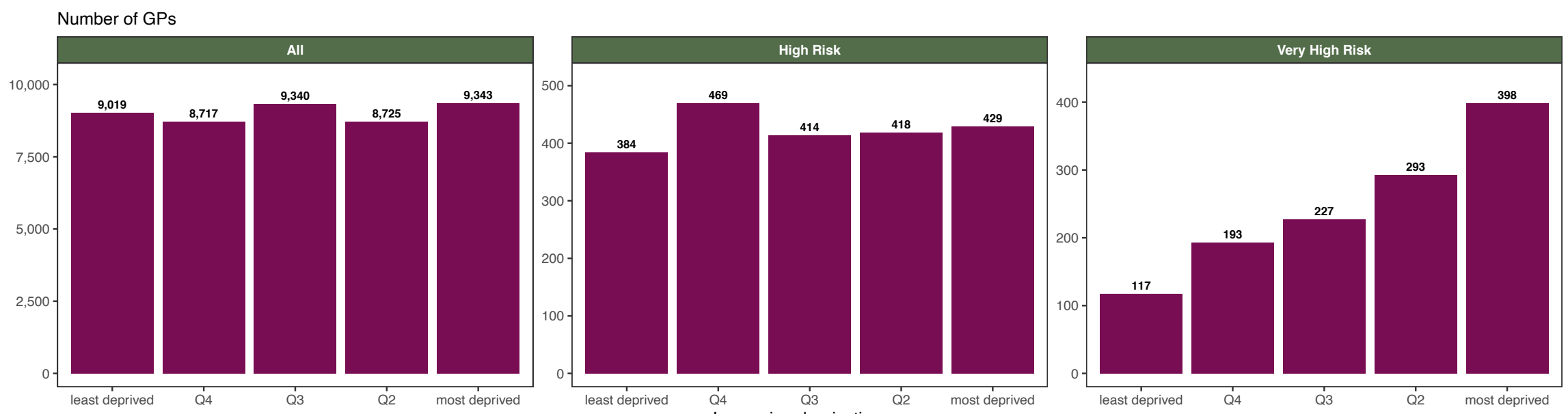

Notes: Data from the NHS Digital General Practice Workforce for 31 March 2020, COVID-19 risk scores: Low (0-1), Medium (1-4), High (4-9), Very High (>9), deprivation quintiles based on population weighted Index of Multiple Deprivation 2019 rank at CCG level 
Figure 3: Socioeconomic distribution of single-handed GP practices run by GPs with high and very high COVID-19 mortality risk
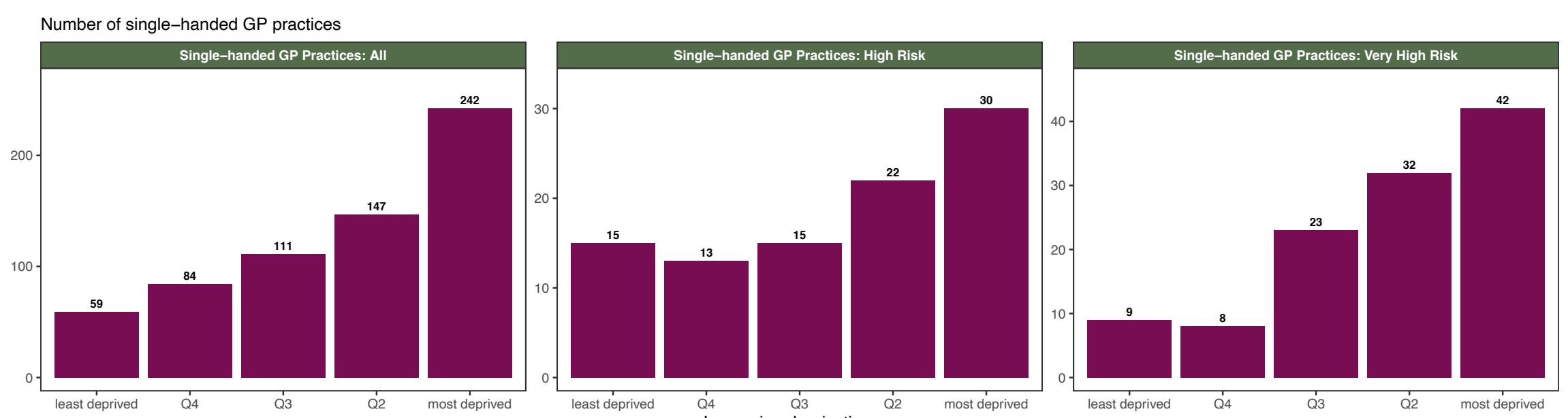

Notes: Data from the NHS Digital General Practice Workforce for 31 March 2020, COVID-19 risk scores: Low (0-1), Medium (1-4), High (4-9), Very High (>9), deprivation quintiles based on population weighted Index of Multiple Deprivation 2019 rank at CCG level 
Figure 4: Socioeconomic distribution of patients registered at single-handed GP practices run by GPs with high and very high COVID-19 mortality risk

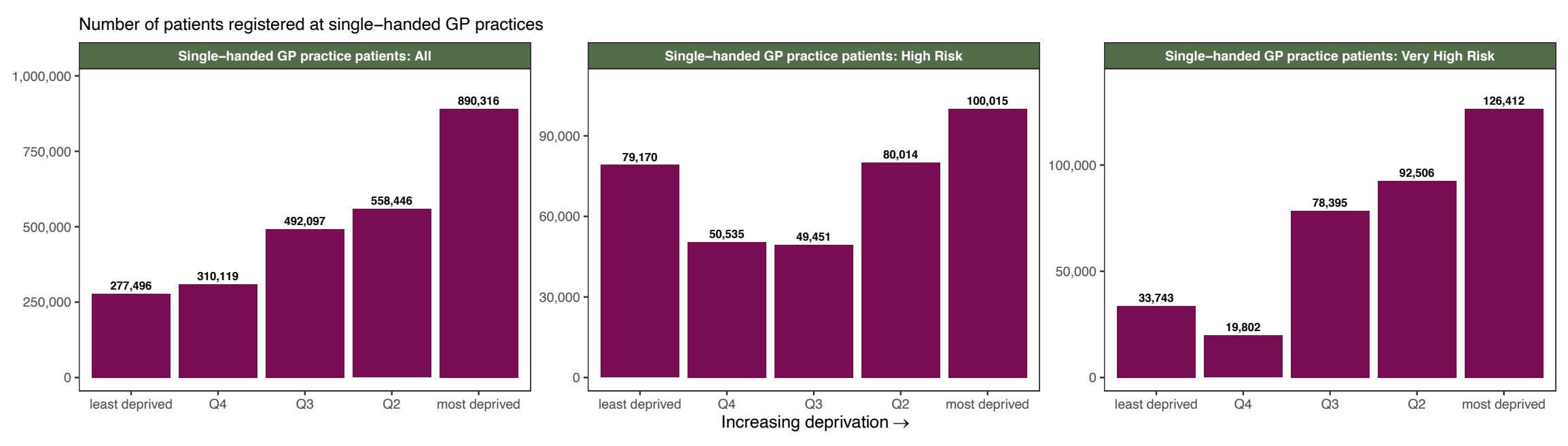

Notes: Data from the NHS Digital General Practice Workforce for 31 March 2020, COVID-19 risk scores: Low (0-1), Medium (1-4), High (4-9), Very High (>9), deprivation quintiles based on population weighted Index of Multiple Deprivation 2019 rank at CCG level 
medRxiv preprint doi: https://doi.org/10.1101/2020.06.04.20122119; this version posted June 5, 2020. The copyright holder for this preprint (which was not certified by peer review) is the author/funder, who has granted medRxiv a license to display the preprint in perpetuity. It is made available under a CC-BY 4.0 International license .

Figure 5: Regional distribution of GPs, single-handed practices and patients registered to these practices by COVID-19 mortality risk

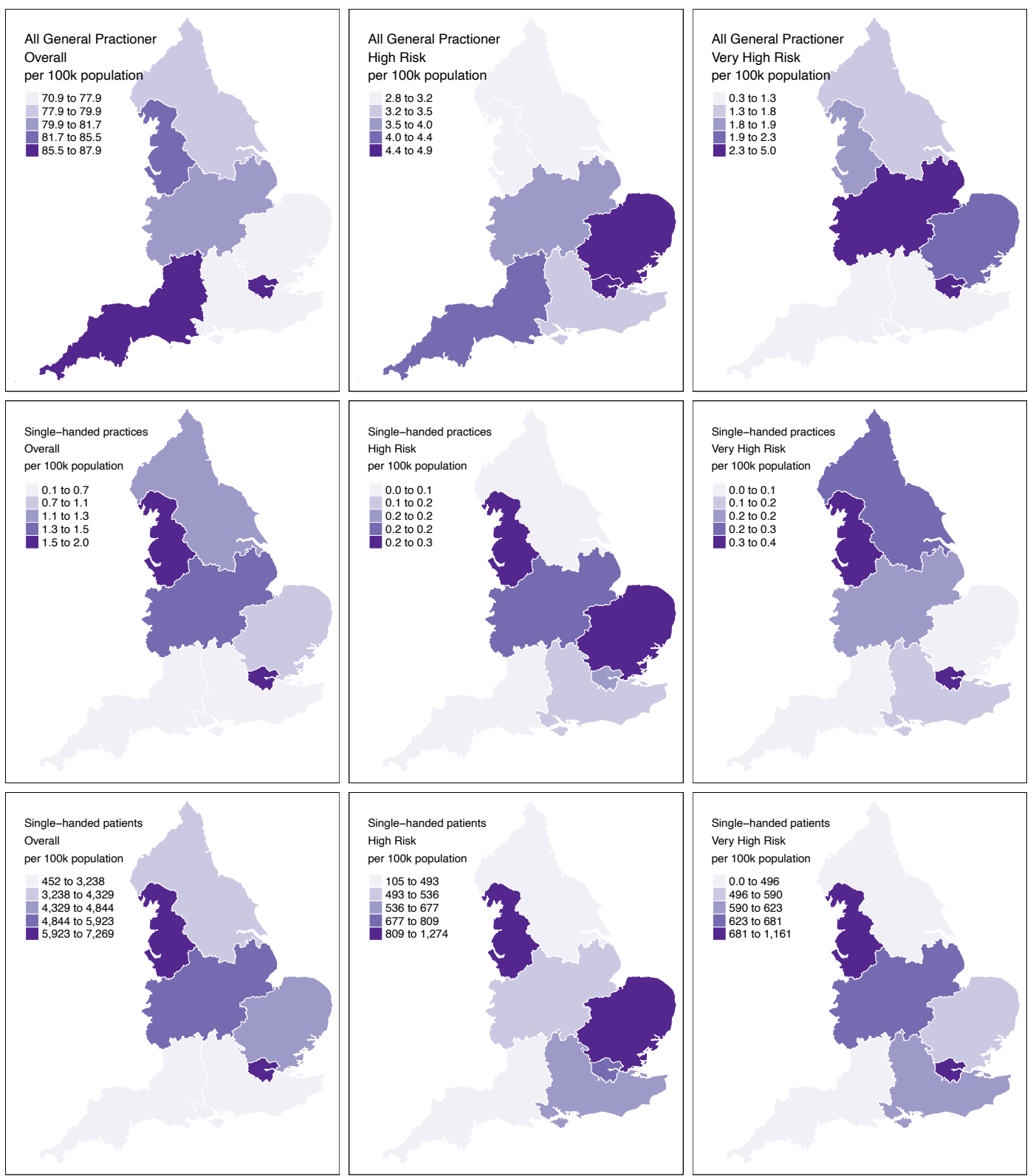

Notes: Population data from ONS 2019 mid-year populations, GP workforce data from the NHS Digital General Practice Workforce for 31 March 2020, COVID-19 risk scores: Low (0-1), Medium (1-4), High (4-9), Very High (>9), map boundaries from Office for National Statistics licensed under the Open Government Licence v.3.0, contains OS data (C) Crown copyright and database right 2019 
medRxiv preprint doi: https://doi.org/10.1101/2020.06.04.20122119; this version posted June 5, 2020. The copyright holder for this preprint (which was not certified by peer review) is the author/funder, who has granted medRxiv a license to display the preprint in perpetuity. It is made available under a CC-BY 4.0 International license .

\section{Supplementary appendix}

Table A1: Population, IMD 2019 score and IMD 2019 quintile for Clinical Commissioning Groups as of April 2020

\begin{tabular}{|c|c|c|c|c|}
\hline $\begin{array}{l}\text { CCG } \\
\text { Code }\end{array}$ & $\begin{array}{c}\text { CCG Name } \\
\text { (from April 2020) }\end{array}$ & $\begin{array}{l}\text { Population } \\
\text { (mid-2018) }\end{array}$ & $\begin{array}{l}\text { IMD } 2019 \\
\text { Score }\end{array}$ & $\begin{array}{c}\text { IMD } 2019 \\
\text { Quintile }\end{array}$ \\
\hline OOR & NHS Blackpool CCG & 139,305 & 45.39 & 1 \\
\hline $01 \mathrm{~J}$ & NHS Knowsley CCG & 149,571 & 43.14 & 1 \\
\hline $99 \mathrm{~A}$ & NHS Liverpool CCG & 494,814 & 42.44 & 1 \\
\hline $03 \mathrm{~F}$ & NHS Hull CCG & 260,645 & 40.58 & 1 \\
\hline $14 \mathrm{~L}$ & NHS Manchester CCG & 547,627 & 39.87 & 1 \\
\hline 05L & NHS Sandwell and West Birmingham CCG & 504,641 & 37.78 & 1 \\
\hline $00 Q$ & NHS Blackburn with Darwen CCG & 148,942 & 36.15 & 1 \\
\hline 01D & NHS Heywood, Middleton and Rochdale CCG & 220,001 & 34.67 & 1 \\
\hline $01 G$ & NHS Salford CCG & 254,408 & 34.32 & 1 \\
\hline 05W & NHS Stoke on Trent CCG & 264,149 & 33.99 & 1 \\
\hline oOY & NHS Oldham CCG & 235,623 & 33.69 & 1 \\
\hline $15 \mathrm{E}$ & NHS Birmingham and Solihull CCG & $1,179,020$ & 33.62 & 1 \\
\hline 36 & NHS Bradford District and Craven CCG & 587,936 & 32.93 & 1 \\
\hline 01T & NHS South Sefton CCG & 159,237 & 32.79 & 1 \\
\hline 07L & NHS Barking and Dagenham CCG & 211,998 & 32.74 & 1 \\
\hline 06A & NHS Wolverhampton CCG & 262,008 & 32.41 & 1 \\
\hline $01 \mathrm{~F}$ & NHS Halton CCG & 128,432 & 32.34 & 1 \\
\hline $05 Y$ & NHS Walsall CCG & 283,378 & 32.07 & 1 \\
\hline 07T & NHS City and Hackney CCG & 288,371 & 32.03 & 1 \\
\hline $01 x$ & NHS St Helens CCG & 180,049 & 31.69 & 1 \\
\hline OON & NHS South Tyneside CCG & 150,265 & 31.68 & 1 \\
\hline 03H & NHS North East Lincolnshire CCG & 159,821 & 31.34 & 1 \\
\hline ООТ & NHS Bolton CCG & 285,372 & 31.03 & 1 \\
\hline
\end{tabular}


medRxiv preprint doi: https://doi.org/10.1101/2020.06.04.20122119; this version posted June 5, 2020. The copyright holder for this preprint (which was not certified by peer review) is the author/funder, who has granted medRxiv a license to display the preprint in perpetuity. it is made available under a CC-BY 4.0 International license.

\begin{tabular}{|c|c|c|c|c|}
\hline $\begin{array}{l}\text { CCG } \\
\text { Code }\end{array}$ & $\begin{array}{c}\text { CCG Name } \\
\text { (from April 2020) }\end{array}$ & $\begin{array}{l}\text { Population } \\
\text { (mid-2018) }\end{array}$ & $\begin{array}{c}\text { IMD } 2019 \\
\text { Score }\end{array}$ & $\begin{array}{c}\text { IMD } 2019 \\
\text { Quintile }\end{array}$ \\
\hline $16 C$ & NHS Tees Valley CCG & 674,284 & 30.96 & 1 \\
\hline 04C & NHS Leicester City CCG & 355,218 & 30.84 & 1 \\
\hline OOP & NHS Sunderland CCG & 277,417 & 30.70 & 1 \\
\hline $02 X$ & NHS Doncaster CCG & 310,542 & 30.46 & 1 \\
\hline 02P & NHS Barnsley CCG & 245,199 & 29.99 & 1 \\
\hline $01 Y$ & NHS Tameside and Glossop CCG & 258,613 & 29.75 & 1 \\
\hline $12 \mathrm{~F}$ & NHS Wirral CCG & 323,235 & 29.73 & 1 \\
\hline $01 \mathrm{~A}$ & NHS East Lancashire CCG & 380,013 & 29.63 & 1 \\
\hline 03L & NHS Rotherham CCG & 264,671 & 29.63 & 1 \\
\hline $08 \mathrm{M}$ & NHS Newham CCG & 352,005 & 29.49 & 1 \\
\hline $13 \mathrm{~T}$ & NHS Newcastle Gateshead CCG & 502,704 & 29.28 & 1 \\
\hline 03J & NHS North Kirklees CCG & 192,750 & 28.88 & 1 \\
\hline $08 \mathrm{~V}$ & NHS Tower Hamlets CCG & 317,705 & 27.63 & 2 \\
\hline $15 \mathrm{~F}$ & NHS Leeds CCG & 789,194 & 27.58 & 2 \\
\hline 03R & NHS Wakefield CCG & 345,038 & 27.36 & 2 \\
\hline $03 N$ & NHS Sheffield CCG & 582,506 & 27.25 & 2 \\
\hline $10 \mathrm{R}$ & NHS Portsmouth CCG & 215,133 & 27.20 & 2 \\
\hline $10 \mathrm{x}$ & NHS Southampton CCG & 252,796 & 26.88 & 2 \\
\hline $84 \mathrm{H}$ & NHS County Durham CCG & 526,980 & 26.61 & 2 \\
\hline $02 \mathrm{~T}$ & NHS Calderdale CCG & 210,082 & 26.46 & 2 \\
\hline 06P & NHS Luton CCG & 214,109 & 26.05 & 2 \\
\hline $02 \mathrm{H}$ & NHS Wigan Borough CCG & 326,088 & 25.89 & 2 \\
\hline 07P & NHS Brent CCG & 330,795 & 25.66 & 2 \\
\hline $08 \mathrm{~W}$ & NHS Waltham Forest CCG & 276,700 & 25.24 & 2 \\
\hline $05 x$ & NHS Telford and Wrekin CCG & 177,799 & 24.99 & 2 \\
\hline 05C & NHS Dudley CCG & 320,626 & 24.31 & 2 \\
\hline
\end{tabular}


medRxiv preprint doi: https://doi.org/10.1101/2020.06.04.20122119; this version posted June 5, 2020. The copyright holder for this preprint (which was not certified by peer review) is the author/funder, who has granted medRxiv a license to display the preprint in perpetuity. It is made available under a CC-BY 4.0 International license.

\begin{tabular}{|c|c|c|c|c|}
\hline $\begin{array}{l}\text { CCG } \\
\text { Code }\end{array}$ & $\begin{array}{c}\text { CCG Name } \\
\text { (from April 2020) }\end{array}$ & $\begin{array}{l}\text { Population } \\
\text { (mid-2018) }\end{array}$ & $\begin{array}{c}\text { IMD } 2019 \\
\text { Score } \\
\end{array}$ & $\begin{array}{c}\text { IMD } 2019 \\
\text { Quintile }\end{array}$ \\
\hline $01 \mathrm{E}$ & NHS Greater Preston CCG & 202,562 & 24.07 & 2 \\
\hline OOV & NHS Bury CCG & 190,108 & 23.92 & 2 \\
\hline $52 \mathrm{R}$ & NHS Nottingham and Nottinghamshire CCG & $1,037,356$ & 23.68 & 2 \\
\hline $10 \mathrm{~L}$ & NHS Isle of Wight CCG & 141,538 & 23.33 & 2 \\
\hline 05A & NHS Coventry and Rugby CCG & 473,979 & 23.27 & 2 \\
\hline $11 \mathrm{~N}$ & NHS Kernow CCG & 568,210 & 23.01 & 2 \\
\hline $93 \mathrm{C}$ & NHS North Central London CCG & $1,498,001$ & 22.97 & 2 \\
\hline 07W & NHS Ealing CCG & 341,982 & 22.75 & 2 \\
\hline $02 Q$ & NHS Bassetlaw CCG & 116,839 & 22.75 & 2 \\
\hline 06T & NHS North East Essex CCG & 338,326 & 22.68 & 2 \\
\hline 03A & NHS Greater Huddersfield CCG & 245,977 & 22.56 & 2 \\
\hline 99G & NHS Southend CCG & 182,463 & 22.55 & 2 \\
\hline 08C & NHS Hammersmith and Fulham CCG & 185,426 & 22.33 & 2 \\
\hline $08 Y$ & NHS West London CCG & 226,099 & 22.28 & 2 \\
\hline $72 Q$ & NHS South East London CCG & $1,811,249$ & 22.25 & 3 \\
\hline 03K & NHS North Lincolnshire CCG & 172,005 & 22.22 & 3 \\
\hline $99 C$ & NHS North Tyneside CCG & 205,985 & 22.22 & 3 \\
\hline OOL & NHS Northumberland CCG & 320,274 & 22.08 & 3 \\
\hline $05 \mathrm{H}$ & NHS Warwickshire North CCG & 193,752 & 21.80 & 3 \\
\hline $01 \mathrm{H}$ & NHS North Cumbria CCG & 318,631 & 21.79 & 3 \\
\hline $01 \mathrm{~K}$ & NHS Morecambe Bay CCG & 330,572 & 21.72 & 3 \\
\hline $26 \mathrm{~A}$ & NHS Norfolk \& Waveney CCG & $1,021,991$ & 21.72 & 3 \\
\hline $07 Y$ & NHS Hounslow CCG & 270,782 & 21.57 & 3 \\
\hline 07G & NHS Thurrock CCG & 172,525 & 21.08 & 3 \\
\hline $01 W$ & NHS Stockport CCG & 291,775 & 20.99 & 3 \\
\hline 09D & NHS Brighton and Hove CCG & 290,395 & 20.86 & 3 \\
\hline
\end{tabular}


medRxiv preprint doi: https://doi.org/10.1101/2020.06.04.20122119; this version posted June 5, 2020. The copyright holder for this preprint (which was not certified by peer review) is the author/funder, who has granted medRxiv a license to display the preprint in perpetuity. It is made available under a CC-BY 4.0 international license.

\begin{tabular}{|c|c|c|c|c|}
\hline $\begin{array}{l}\text { CCG } \\
\text { Code }\end{array}$ & $\begin{array}{c}\text { CCG Name } \\
\text { (from April 2020) }\end{array}$ & $\begin{array}{l}\text { Population } \\
\text { (mid-2018) }\end{array}$ & $\begin{array}{c}\text { IMD } 2019 \\
\text { Score } \\
\end{array}$ & $\begin{array}{c}\text { IMD } 2019 \\
\text { Quintile }\end{array}$ \\
\hline $15 \mathrm{M}$ & NHS Derby and Derbyshire CCG & $1,019,900$ & 20.51 & 3 \\
\hline 910 & NHS Kent and Medway CCG & $1,846,478$ & 20.36 & 3 \\
\hline $71 \mathrm{E}$ & NHS Lincolnshire CCG & 755,833 & 20.27 & 3 \\
\hline $15 N$ & NHS Devon CCG & $1,194,166$ & 20.17 & 3 \\
\hline $97 R$ & $\begin{array}{l}\text { NHS East Sussex CCG } \\
\text { NHS Bristol, North Somerset and South }\end{array}$ & 554,590 & 19.80 & 3 \\
\hline $15 C$ & Gloucestershire CCG & 959,968 & 19.72 & 3 \\
\hline $01 \mathrm{~V}$ & NHS Southport and Formby CCG & 116,159 & 19.51 & 4 \\
\hline $99 \mathrm{E}$ & NHS Basildon and Brentwood CCG & 262,412 & 19.49 & 4 \\
\hline $04 Y$ & NHS Cannock Chase CCG & 136,974 & 19.28 & 4 \\
\hline O2E & NHS Warrington CCG & 209,547 & 19.05 & 4 \\
\hline $78 \mathrm{H}$ & NHS Northamptonshire CCG & 730,650 & 18.78 & 4 \\
\hline 02M & NHS Fylde and Wyre CCG & 192,421 & 18.66 & 4 \\
\hline 02G & NHS West Lancashire CCG & 113,949 & 18.61 & 4 \\
\hline $11 X$ & NHS Somerset CCG & 559,399 & 18.60 & 4 \\
\hline 09A & NHS Central London (Westminster) CCG & 185,422 & 18.55 & 4 \\
\hline 08G & NHS Hillingdon CCG & 304,824 & 18.36 & 4 \\
\hline $18 \mathrm{C}$ & NHS Herefordshire and Worcestershire CCG & 784,164 & 18.32 & 4 \\
\hline 05D & NHS East Staffordshire CCG & 128,418 & 18.25 & 4 \\
\hline 04F & NHS Milton Keynes CCG & 275,002 & 17.77 & 4 \\
\hline 06L & NHS Ipswich and East Suffolk CCG & 409,248 & 17.72 & 4 \\
\hline $00 \mathrm{X}$ & NHS Chorley and South Ribble CCG & 176,862 & 17.70 & 4 \\
\hline 05G & NHS North Staffordshire CCG & 219,571 & 17.62 & 4 \\
\hline $08 \mathrm{~N}$ & NHS Redbridge CCG & 303,858 & 17.30 & 4 \\
\hline $05 N$ & NHS Shropshire CCG & 320,274 & 17.13 & 4 \\
\hline $11 \mathrm{~J}$ & NHS Dorset CCG & 772,268 & 17.05 & 4 \\
\hline $08 \mathrm{~F}$ & NHS Havering CCG & 257,810 & 17.03 & 4 \\
\hline
\end{tabular}


medRxiv preprint doi: https://doi.org/10.1101/2020.06.04.20122119; this version posted June 5, 2020. The copyright holder for this preprint (which was not certified by peer review) is the author/funder, who has granted medRxiv a license to display the preprint in perpetuity. It is made available under a CC-BY 4.0 International license.

\begin{tabular}{|c|c|c|c|c|}
\hline $\begin{array}{l}\text { CCG } \\
\text { Code }\end{array}$ & $\begin{array}{c}\text { CCG Name } \\
\text { (from April 2020) }\end{array}$ & $\begin{array}{l}\text { Population } \\
\text { (mid-2018) }\end{array}$ & $\begin{array}{l}\text { IMD } 2019 \\
\text { Score } \\
\end{array}$ & $\begin{array}{c}\text { IMD } 2019 \\
\text { Quintile }\end{array}$ \\
\hline $10 \mathrm{~V}$ & NHS South Eastern Hampshire CCG & 216,379 & 16.94 & 4 \\
\hline $06 \mathrm{H}$ & NHS Cambridgeshire and Peterborough CCG & 889,112 & 16.85 & 4 \\
\hline 27D & NHS Cheshire CCG & 721,292 & 16.21 & 4 \\
\hline $02 \mathrm{~A}$ & NHS Trafford CCG & 236,370 & 16.13 & 4 \\
\hline $02 Y$ & NHS East Riding of Yorkshire CCG & 317,404 & 16.09 & 4 \\
\hline 07K & NHS West Suffolk CCG & 230,997 & 15.99 & 4 \\
\hline $36 \mathrm{~L}$ & NHS South West London CCG & $1,494,905$ & 15.99 & 4 \\
\hline $42 \mathrm{D}$ & NHS North Yorkshire CCG & 426,821 & 15.65 & 4 \\
\hline & NHS South East Staffordshire and Seisdon & & & \\
\hline $05 Q$ & Peninsula CCG & 226,137 & 15.52 & 5 \\
\hline 07H & NHS West Essex CCG & 306,910 & 15.16 & 5 \\
\hline $08 \mathrm{E}$ & NHS Harrow CCG & 250,149 & 15.10 & 5 \\
\hline $11 \mathrm{M}$ & NHS Gloucestershire CCG & 633,558 & 14.94 & 5 \\
\hline $06 \mathrm{~F}$ & NHS Bedfordshire CCG & 455,229 & 14.75 & 5 \\
\hline $70 F$ & NHS West Sussex CCG & 858,852 & 14.44 & 5 \\
\hline & NHS Bath and North East Somerset, Swindon and & & & \\
\hline $92 \mathrm{G}$ & Wiltshire CCG & 918,428 & 14.28 & 5 \\
\hline $15 \mathrm{D}$ & NHS East Berkshire CCG & 434,463 & 13.99 & 5 \\
\hline $10 K$ & NHS Fareham and Gosport CCG & 201,622 & 13.96 & 5 \\
\hline 06K & NHS East and North Hertfordshire CCG & 569,078 & 13.80 & 5 \\
\hline $99 F$ & NHS Castle Point and Rochford CCG & 177,051 & 13.70 & 5 \\
\hline 06Q & NHS Mid Essex CCG & 393,065 & 13.56 & 5 \\
\hline $05 \mathrm{~V}$ & NHS Stafford and Surrounds CCG & 155,803 & 13.55 & 5 \\
\hline $04 \mathrm{~V}$ & NHS West Leicestershire CCG & 402,165 & 13.29 & 5 \\
\hline 10J & NHS North Hampshire CCG & 223,795 & 12.12 & 5 \\
\hline $03 Q$ & NHS Vale of York CCG & 362,955 & 11.96 & 5 \\
\hline $06 \mathrm{~N}$ & NHS Herts Valleys CCG & 595,670 & 11.94 & 5 \\
\hline 05R & NHS South Warwickshire CCG & 270,064 & 11.89 & 5 \\
\hline
\end{tabular}


medRxiv preprint doi: https://doi.org/10.1101/2020.06.04.20122119; this version posted June 5, 2020. The copyright holder for this preprint (which was not certified by peer review) is the author/funder, who has granted medRxiv a license to display the preprint in perpetuity. It is made available under a CC-BY 4.0 International license .

\begin{tabular}{|c|c|c|c|c|}
\hline $\begin{array}{l}\text { CCG } \\
\text { Code }\end{array}$ & $\begin{array}{c}\text { CCG Name } \\
\text { (from April 2020) }\end{array}$ & $\begin{array}{l}\text { Population } \\
\text { (mid-2018) }\end{array}$ & $\begin{array}{c}\text { IMD } 2019 \\
\text { Score }\end{array}$ & $\begin{array}{l}\text { IMD } 2019 \\
\text { Quintile }\end{array}$ \\
\hline $15 \mathrm{~A}$ & NHS Berkshire West CCG & 489,709 & 11.80 & 5 \\
\hline $10 Q$ & NHS Oxfordshire CCG & 672,414 & 11.72 & 5 \\
\hline $11 \mathrm{~A}$ & NHS West Hampshire CCG & 566,879 & 11.37 & 5 \\
\hline 03W & NHS East Leicestershire and Rutland CCG & 335,800 & 10.78 & 5 \\
\hline $99 M$ & NHS North East Hampshire and Farnham CCG & 211,590 & 10.40 & 5 \\
\hline $92 \mathrm{~A}$ & NHS Surrey Heartlands CCG & $1,036,742$ & 10.32 & 5 \\
\hline $14 Y$ & NHS Buckinghamshire CCG & 542,512 & 10.15 & 5 \\
\hline $10 \mathrm{C}$ & NHS Surrey Heath CCG & 96,474 & 9.24 & 5 \\
\hline
\end{tabular}

Table A2: Distribution of COVID-19 mortality risk by age, sex and ethnicity - data underpinning figure 1

\begin{tabular}{|c|c|c|c|c|c|c|c|c|c|}
\hline $\begin{array}{l}\text { Age } \\
\text { Group }\end{array}$ & Sex & Ethnicity & $\begin{array}{l}\text { COVID-19 } \\
\text { mortality risk }\end{array}$ & $\begin{array}{l}\text { All } \\
\text { GPs }\end{array}$ & $\begin{array}{l}\text { GP } \\
\text { Partners }\end{array}$ & $\begin{array}{l}\text { Salaried } \\
\text { GPs }\end{array}$ & $\begin{array}{l}\text { GP } \\
\text { Locums }\end{array}$ & $\begin{array}{l}\text { GP } \\
\text { Registrars }\end{array}$ & $\begin{array}{l}\text { GP } \\
\text { Retainers }\end{array}$ \\
\hline & & & & 106 & 79 & 10 & 17 & 0 & 0 \\
\hline \multirow[t]{2}{*}{$70+$} & Female & BAME & Very High & $(0.23 \%)$ & (0.17\%) & $(0.02 \%)$ & $(0.04 \%)$ & $(0 \%)$ & $(0 \%)$ \\
\hline & & & & 29 & 14 & 5 & 10 & 0 & 0 \\
\hline \multirow{2}{*}{$70+$} & Female & White & Very High & (0.06\%) & (0.03\%) & $(0.01 \%)$ & $(0.02 \%)$ & (0\%) & (0\%) \\
\hline & & & & 417 & 307 & 36 & 73 & & 1 \\
\hline \multirow[t]{2}{*}{$70+$} & Male & BAME & Very High & (0.91\%) & (0.67\%) & $(0.08 \%)$ & $(0.16 \%)$ & $0(0 \%)$ & (0\%) \\
\hline & & & & 74 & 33 & 14 & 24 & & 3 \\
\hline \multirow[t]{2}{*}{$70+$} & Male & White & Very High & (0.16\%) & $(0.07 \%)$ & $(0.03 \%)$ & $(0.05 \%)$ & $0(0 \%)$ & $(0.01 \%)$ \\
\hline & & & & 753 & 534 & 101 & 111 & 3 & 4 \\
\hline \multirow[t]{2}{*}{$60-69$} & Male & BAME & Very High & (1.64\%) & (1.16\%) & $(0.22 \%)$ & $(0.24 \%)$ & (0.01\%) & (0.01\%) \\
\hline & & & & 316 & 184 & 75 & 55 & 0 & 2 \\
\hline \multirow[t]{2}{*}{$60-69$} & Female & BAME & High & (0.69\%) & $(0.4 \%)$ & $(0.16 \%)$ & $(0.12 \%)$ & $(0 \%)$ & (0\%) \\
\hline & & & & 1,515 & 1,066 & 216 & 184 & 1 & 48 \\
\hline \multirow[t]{2}{*}{$60-69$} & Male & White & High & (3.3\%) & $(2.32 \%)$ & $(0.47 \%)$ & $(0.4 \%)$ & $(0 \%)$ & (0.1\%) \\
\hline & & & & 422 & 301 & 66 & 49 & 5 & 1 \\
\hline \multirow[t]{2}{*}{$55-59$} & Male & BAME & High & (0.92\%) & $(0.66 \%)$ & (0.14\%) & (0.11\%) & $(0.01 \%)$ & (0\%) \\
\hline & & & & 654 & 374 & 180 & 65 & 0 & 35 \\
\hline \multirow[t]{2}{*}{$60-69$} & Female & White & Medium & (1.43\%) & (0.82\%) & $(0.39 \%)$ & $(0.14 \%)$ & (0\%) & (0.08\%) \\
\hline & & & & 328 & 198 & 88 & 35 & 2 & \\
\hline \multirow[t]{2}{*}{$55-59$} & Female & BAME & Medium & (0.72\%) & $(0.43 \%)$ & (0.19\%) & $(0.08 \%)$ & (0\%) & $5(0.01 \%)$ \\
\hline & & & & 1,701 & 1,433 & 163 & 91 & 0 & 14 \\
\hline \multirow[t]{2}{*}{$55-59$} & Male & White & Medium & (3.71\%) & (3.12\%) & $(0.36 \%)$ & $(0.2 \%)$ & $(0 \%)$ & $(0.03 \%)$ \\
\hline & & & & 1,402 & 960 & 335 & 79 & 0 & 28 \\
\hline \multirow[t]{2}{*}{$55-59$} & Female & White & Low & (3.06\%) & (2.09\%) & $(0.73 \%)$ & $(0.17 \%)$ & $(0 \%)$ & $(0.06 \%)$ \\
\hline & & & & 4,694 & 1,407 & 1,771 & 622 & 850 & 44 \\
\hline \multirow[t]{2}{*}{$<55$} & Female & BAME & Low & $(10.24 \%)$ & (3.07\%) & (3.86\%) & (1.36\%) & (1.85\%) & (0.1\%) \\
\hline & & & & 18,074 & 6,109 & 7,316 & 1,307 & 3,012 & 330 \\
\hline \multirow[t]{2}{*}{$<55$} & Female & White & Low & (39.41\%) & (13.32\%) & (15.95\%) & (2.85\%) & (6.57\%) & $(0.72 \%)$ \\
\hline & & & & 3,945 & 1,797 & 821 & 590 & 735 & 2 \\
\hline \multirow[t]{2}{*}{$<55$} & Male & BAME & Low & (8.6\%) & (3.92\%) & (1.79\%) & (1.29\%) & (1.6\%) & (0\%) \\
\hline & & & & 11,428 & 6,183 & 2,322 & 1,172 & 1,731 & 20 \\
\hline$<55$ & Male & White & Low & (24.92\%) & (13.48\%) & (5.06\%) & $(2.56 \%)$ & (3.77\%) & $(0.04 \%)$ \\
\hline
\end{tabular}


medRxiv preprint doi: https://doi.org/10.1101/2020.06.04.20122119; this version posted June 5, 2020. The copyright holder for this preprint (which was not certified by peer review) is the author/funder, who has granted medRxiv a license to display the preprint in perpetuity. t is made available under a CC-BY 4.0 International license.

Table A3: Distribution of COVID-19 mortality risk for GPs by CCG IMD quintile - data underpinning figure 2

\begin{tabular}{lrrr}
\hline IMD 2019 Quintile & All GPs & High Risk GPs & Very High Risk GPs \\
\hline Q5 least deprived & 9,012 & 414 & 143 \\
Q4 & 8,707 & 488 & 209 \\
Q3 & 9,332 & 464 & 290 \\
Q2 & 8,713 & 437 & 312 \\
Q1 most deprived & 9,331 & 450 & 425 \\
Unknown & 763 & 0 & 0 \\
\hline
\end{tabular}

Table A4: Distribution of COVID-19 mortality risk for single handed GP practices by IMD quintile - data underpinning figure 3

\begin{tabular}{|c|c|c|c|}
\hline IMD 2019 Quintile & All & High Risk & Very High Risk \\
\hline Q5 least deprived & 59 & 15 & 9 \\
\hline Q4 & 84 & 13 & 8 \\
\hline Q3 & 111 & 15 & 23 \\
\hline Q2 & 146 & 22 & 32 \\
\hline Q1 most deprived & 239 & 30 & 42 \\
\hline
\end{tabular}

Table A5: Distribution of COVID-19 mortality risk for patients registered to single handed GP practices by IMD quintile - data underpinning figure 4

\begin{tabular}{lrrr}
\hline IMD 2019 Quintile & \multicolumn{1}{c}{ All } & \multicolumn{1}{c}{ High Risk } & \multicolumn{1}{c}{ Very High Risk } \\
\hline Q5 least deprived & 277,496 & 79,170 & 33,743 \\
Q4 & 310,119 & 50,535 & 19,802 \\
Q3 & 492,097 & 49,451 & 78,395 \\
Q2 & 546,183 & 80,014 & 92,506 \\
Q1 most deprived & 871,264 & 100,015 & 126,412 \\
\hline
\end{tabular}

Table A6: Rates of GPs, single-handed GP practices, and patients registered to singlehanded GP practices per 100,000 population

\begin{tabular}{|c|c|c|c|c|c|c|c|c|c|}
\hline Region & $\begin{array}{c}\text { All General } \\
\text { Practioners } \\
\text { Overall }\end{array}$ & $\begin{array}{c}\text { All General } \\
\text { Practioners } \\
\text { High Risk }\end{array}$ & $\begin{array}{c}\text { All General } \\
\text { Practioners } \\
\text { Very High } \\
\text { Risk }\end{array}$ & $\begin{array}{l}\text { Single- } \\
\text { handed } \\
\text { practices } \\
\text { Overall }\end{array}$ & $\begin{array}{c}\text { Single- } \\
\text { handed } \\
\text { practices } \\
\text { High Risk }\end{array}$ & $\begin{array}{c}\text { Single- } \\
\text { handed } \\
\text { practices } \\
\text { Very High } \\
\text { Risk } \\
\end{array}$ & $\begin{array}{c}\text { Single- } \\
\text { handed } \\
\text { patients } \\
\text { Overall }\end{array}$ & $\begin{array}{l}\text { Single- } \\
\text { handed } \\
\text { patients } \\
\text { High Risk }\end{array}$ & $\begin{array}{c}\text { Single- } \\
\text { handed } \\
\text { patients } \\
\text { Very High } \\
\text { Risk }\end{array}$ \\
\hline East of England & 70.84 & 4.53 & 2.11 & 1.03 & 0.28 & 0.14 & 4,684 & 1,273 & 580 \\
\hline London & 86.16 & 5.00 & 5.22 & 1.47 & 0.17 & 0.37 & 6,028 & 741 & 1,160 \\
\hline Midlands & 80.14 & 3.90 & 2.47 & 1.37 & 0.19 & 0.20 & 4,950 & 505 & 634 \\
\hline $\begin{array}{l}\text { North East and } \\
\text { Yorkshire }\end{array}$ & 79.55 & 3.08 & 1.95 & 1.13 & 0.14 & 0.21 & 4,092 & 489 & 475 \\
\hline North West & 82.45 & 3.44 & 2.10 & 1.94 & 0.21 & 0.29 & 6,996 & 826 & 692 \\
\hline South East & 77.39 & 4.08 & 2.03 & 0.66 & 0.15 & 0.15 & 3,023 & 581 & 605 \\
\hline South West & 87.89 & 4.23 & 0.41 & 0.11 & 0.04 & - & 451 & 105 & - \\
\hline
\end{tabular}

